\title{
Ejaculate Quality is Influenced by Boar Behaviour at the Time of Collection
}

\author{
Vasile MICLEA $^{1 *}$, Ilona GYORGY ${ }^{2}$, Ileana MICLEA ${ }^{1}$, Marius ZĂHAN ${ }^{1}$, Alexandru NAGY ${ }^{3}$, Aurel POTRA ${ }^{1}$ \\ ${ }^{1}$ Department of Animal Reproduction, University of Agricultural Sciences and Veterinary Medicine \\ Cluj-Napoca, Romania. \\ ${ }^{2}$ S.C.SEMTEST BVN S.A. Târgu Mureş, Romania. \\ ${ }^{3}$ SCDA Turda, Romania. \\ * corresponding author: vasilemiclea21@yahoo.com
}

Bulletin UASVM Animal Science and Biotechnologies 73(2)/ 2016

Print ISSN 1843-5262; Electronic ISSN 1843-536X

DOI:10.15835/buasvmcn-asb: 12208

\begin{abstract}
Ejaculates were collected from the same boars twice a week, in spring during two years. Most animals had very good sexual reflexes and were scored as 5 . They gave ejaculates which had good volume, concentration and motility and could be processed into the largest number of insemination doses. This had an obvious positive economic effect. Age influenced ejaculate quality in young boars, with the exception of a few animals in which sexual reflexes were diminished. Nevertheless, ejaculates had the necessary characteristics and could be processed.
\end{abstract}

Keywords: behaviour, boars, ejaculates, quality

\section{INTRODUCTION}

Neural and hormonal pathways control boar sexual behaviour and functions of the reproductive system (Păcală, 2000, Acatincăi, 2003). Based on this correlation we can predict the reproductive characteristics of a boar based on sexual behaviour (Miclea, 2008). Behaviour assessment enables us to correctly and accurately select an animal so that it can produce the best results.

\section{AIMS AND OBJECTIVES}

Our aim was to understand and to quantify the influence of sexual reflexes and age on ejaculate quality. This has a far reaching impact on the selection of young boars for reproduction and on collection frequency in adult animals.

\section{MATERIALS AND METHODS}

Boars belonging to the Large White, Landrace, Pietrain and Duroc breeds were kept in similar conditions and fed according to their needs. Between March and May semen was collected twice every week. After collection semen volume was assessed by weighing, concentration was estimated by photometry and mobility was expressed as percentage. Each insemination dose had 3.1 billion spermatozoa per $100 \mathrm{ml}$. Sexual behaviour was assessed on a scale from 1 to 5. Results were processed with the analysis of variance and data are presented in tables.

\section{RESULTS AND DISCUSSION}

During the first year of semen collection, no boar had sexual reflexes scored as 3 , but in some males sexual behaviour becomes less intense with age. However, ejaculate quality allowed processing and the number of insemination doses (Tab. 1) was higher than the one that resulted from boars scored as 4 and which were being monitored for the first year (Tab. 2).

Quality of ejaculates collected in the second year from boars scored as 4 was similar to that of boars in the same year scored as 3 (Tab. 2). In boars with sexual reflexes scored as 4 in both years, ejaculate volume and sperm cell concentration increased the average number of insemination 
Tab. 1 Characteristics of ejaculates from boars with collection behaviour scored as 3

\begin{tabular}{ccccccc}
\hline \multirow{2}{*}{ Characteristics } & \multicolumn{3}{c}{ Year 1} & \multicolumn{3}{c}{ Year 2 } \\
\cline { 2 - 7 } & $\mathrm{x} \pm \mathrm{sx}$ & $\mathrm{s}$ & $\mathrm{v} \%$ & $\mathrm{x} \pm \mathrm{sx}$ & $\mathrm{s}$ & $\mathrm{v} \%$ \\
\hline Volume $-\mathrm{ml}$ & - & - & - & $201.25 \pm 22.78$ & 64.46 & 32.02 \\
\hline Concentration $-\mathrm{n} \times 10^{6}$ & - & - & - & $257.50 \pm 71.50$ & 202.25 & 73.41 \\
\hline $\begin{array}{c}\text { No. of sperm cells in the } \\
\text { ejaculate }-\mathrm{n} \times 10^{9}\end{array}$ & - & - & - & $48.63 \pm 6.25$ & 17.68 & 36.35 \\
\hline Motility - \% & - & - & - & 70.62 & - & - \\
\hline Number of doses & - & - & - & $16.00 \pm 2.13$ & 6.04 & 37.75 \\
\hline
\end{tabular}

Tab. 2 Characteristics of ejaculates from boars with collection behaviour scored as 4

\begin{tabular}{ccccccc}
\hline \multirow{2}{*}{ Characteristics } & \multicolumn{3}{c}{ Year 1 } & \multicolumn{3}{c}{ Year 2 } \\
\cline { 2 - 7 } & $\mathrm{x} \pm \mathrm{sx}$ & $\mathrm{s}$ & $\mathrm{v} \%$ & $\mathrm{x} \pm \mathrm{sx}$ & $\mathrm{s}$ & $\mathrm{v} \%$ \\
\hline Volume $-\mathrm{ml}$ & $178.00 \pm 6.63$ & 14.83 & 8.33 & $215.22 \pm 9.79$ & 65.00 & 30.20 \\
\hline Concentration $-\mathrm{n} \times 10^{6}$ & $240.00 \pm 18.44$ & 41.25 & 17.18 & $252.38 \pm 16.69$ & 110.71 & 43.86 \\
\hline $\begin{array}{c}\text { No. of sperm cells in the } \\
\text { ejaculate - n x 109 }\end{array}$ & $42.99 \pm 4.41$ & 9.87 & 22.95 & $49.78 \pm 2.01$ & 13.33 & 26.77 \\
\hline Motility - \% & 71.00 & - & - & 71.59 & - & - \\
\hline Number of doses & $13.80 \pm 1.46$ & 3.27 & 23.69 & $16.50 \pm 0.68$ & 4.52 & 27.39 \\
\hline
\end{tabular}

Tab. 3 Characteristics of ejaculates from boars with collection behaviour scored as 5

\begin{tabular}{ccccccc}
\hline \multirow{2}{*}{ Characteristics } & \multicolumn{3}{c}{ Year 1} & \multicolumn{3}{c}{ Year 2 } \\
\cline { 2 - 7 } & $\mathrm{x} \pm \mathrm{sx}$ & $\mathrm{s}$ & $\mathrm{v} \%$ & $\mathrm{x} \pm \mathrm{sx}$ & $\mathrm{s}$ & $\mathrm{v} \%$ \\
\hline Volume $-\mathrm{ml}$ & $229.34 \pm 9.73$ & 60.00 & 26.16 & $330.00 \pm 0.78$ & 16.20 & 4.90 \\
\hline Concentration $-\mathrm{n} \times 10^{6}$ & $296.84 \pm 16.81$ & 103.66 & 34.92 & $236.00 \pm 3.89$ & 80.70 & 34.09 \\
\hline $\begin{array}{c}\text { No. of sperm cells in the } \\
\text { ejaculate }-\mathrm{n} \times 10^{9}\end{array}$ & $64.95 \pm 0.56$ & 21.40 & 32.94 & $71.62 \pm 1.23$ & 25.32 & 35.35 \\
\hline Motility - \% & 73.28 & - & - & 73.39 & - & - \\
\hline Number of doses & $21.34 \pm$ & 7.11 & 33.31 & $23.69 \pm 0.40$ & 8.38 & 35.37 \\
\hline
\end{tabular}

doses for each ejaculate from 13.80 to 16.5 (Tab. 2).

Boars with sexual behaviour scored as 5 gave the best ejaculates. These had the largest volume, but a concentration that decreased during the second year (Tab. 3). An increase in volume in the second year resulted in more insemination doses when compared to the first year (Tab. 3). This is because the total number of sperm cells increased. Similar studies were undertaken by Miclea et al. (2008) and Nacu (2008).

\section{CONCLUSION}

There was a close connection between sexual behaviour and ejaculate quality in boars from breeds relevant for meat production. The intensity of sexual reflexes diminished together with ejaculate quality. Sexual behaviour had a major influence on ejaculate volume and sperm cell motility. Boars with sexual behaviour scored as 5 had the best ejaculate quality in the second year and were the most valuable from an economic standpoint.

Acknowledgments. This work was supported by grant ADER 5.1.6/2015 funded by the Ministry of Agriculture and Rural Development, Romania.

\section{REFERENCES}

1. Acatincăi S (2003). Etiologie. Comportamentul animalelor domestice. Ed Eurobit, Timișoara. 
2. Miclea V, Zăhan M, Gyorgy I, Miclea I (2008). Influence of boar age on ejaculate quality. Bull UASVM Cluj-Napoca Animal Science and Biotechnologies 65(1-2):99-103.

3. Nacu G (2008). Researches concerning the sperm production according to the frequency of collecting the seminal material at boars. Lucrări Stiințifice Zootehnie USAMV Iaşi 51:362-365.

4. Păcală N (2000). Biologia reproducerii animalelor. Ed Mirton, Timișoara. 